\title{
Key plant products and common mechanisms utilized by plants in water deficit stress responses
}

Botanical Sciences 94 (4): 657-671, 2016

DOI: $10.17129 /$ botsci.709

\section{Parviz Moradi}

\section{Abstract}

Plants are always exposed to fluctuation of environmental factors. Water stress is one of the main abiotic factors limiting plant growth and development on most areas of the world. Declining available water triggers various adaptive processes to cope with water deficit stress. These mechanisms can be categorized into escape, avoidance and tolerance strategies. Avoidance mechanisms are employed to maintain the balance between water uptake and water loss, while tolerance mechanisms are trying to keep the plant functions the same level as unstressed level. Major molecular mechanisms attributed as tolerance strategies include osmotic adjustment, Reactive Oxygen Species (ROS) scavenging, cellular components protection membrane lipid changes and hormone inductions. Huge number of metabolites contributes to these diverse mechanisms, but broadly can be classified into amino acids, carbohydrates, lipids, proteins and secondary metabolites. In this review, the role of these compounds is discussed in the contributed mechanisms against water deficit stress. Identification of these substances (key plant products) and related biochemical processes of drought tolerance might help plant breeders and researchers in different ways such as shortening and facilitating selection procedures in plant breeding programs, improving drought tolerance of sensitive varieties either by transferring related genes or simply exogenous application.

Key Words: Drought, Compounds, Tolerance, Metabolite, Biochemical, Osmotic

\section{Productos vegetales clave y mecanismos comunes utilizados por las plantas en la respuesta al estrés provocado por el déficit de agua \\ Resumen}

Las plantas se encuentras expuestas a la fluctuación de los factores ambientales. El estrés hídrico es uno de los principales factores abióticos que limitan su crecimiento y desarrollo en muchas regiones del mundo. La disminución en la disponibilidad de agua desencadena varios mecanismos adaptativos que les permiten hacer frente al estrés hídrico. Estos mecanismos se pueden clasificar en estrategias de escape, prevención y tolerancia. Los mecanismos de prevención se usan para mantener el equilibrio entre la captación y la pérdida de agua, mientras que los mecanismos de tolerancia mantienen el funcionamiento de la planta a pesar de las condiciones adversas. Los principales mecanismos moleculares involucrados en las estrategias de tolerancia de las plantas incluyen el ajuste osmótico, las especies reactivas del oxígeno (ERO o ROS por reactive oxygen species), componentes celulares, membranas de protección, cambios en los lípidos e inducción de hormonas. Hay un gran número de metabolitos que contribuyen en estos procesos, pero en términos generales se pueden clasificar en aminoácidos, carbohidratos, lípidos, proteínas y metabolitos secundarios. En esta revisión, se discute el papel de estos compuestos en el estrés hídrico. La identificación de estas sustancias (productos clave de las plantas) y los procesos bioquímicos relacionados con la tolerancia a la sequía podrían ayudar a los productores de plantas e investigadores a seleccionar programas de fito-mejoramiento y optimizar la tolerancia de las variedades susceptibles a la sequía, ya sea mediante la transferencia de genes relacionados o simplemente por aplicación exógena.

Palabras clave: sequía, compuestos vegetales, tolerancia, metabolitos, bioquímica, ajuste osmótico
Research Division of Natural Resources, Zanjan Agricultural and Natural Resources Research and Education Center, AREEO, Zanjan, Iran. Corresponding author p_moradi@areeo.ac.ir 
- here are different terms and expressions in contexts used for drought and related subjects. "Drought" is a meteorological and agricultural term and it means a period of time without significant rainfall. In general, drought reduces the available water in the soil and allows loss of water by evaporation and transpiration continuously due to atmospheric conditions (Jaleel et al. 2007). But "Water deficit" or "dehydration" is used when the water is insufficient for plant metabolism and therefore will affect its growth and development (Hirt \& Shinozaki 2003). Another term "desiccation", which refers to losing free water entirely, namely less than ten percent water content, is left in the plant (equivalent to $0.1 \mathrm{~g}$ water per $1 \mathrm{~g}$ dry matter (Alpert 2005, Alpert 2006). Available water in most herbaceous plants is around $80-90 \%$ of their fresh weight (Kramer \& Boyer 1995), but "water stress" conditions reduce water content which declines plant water potential and turgor pressure.

The effect of drought on plants can be discussed relation to morphological, photosynthesis, proteins, lipids, mineral uptake and ROS (Reactive Oxygen Species) factors as demonstrated in Figure 1 (Lisar et al. 2012, Moradi 2014).

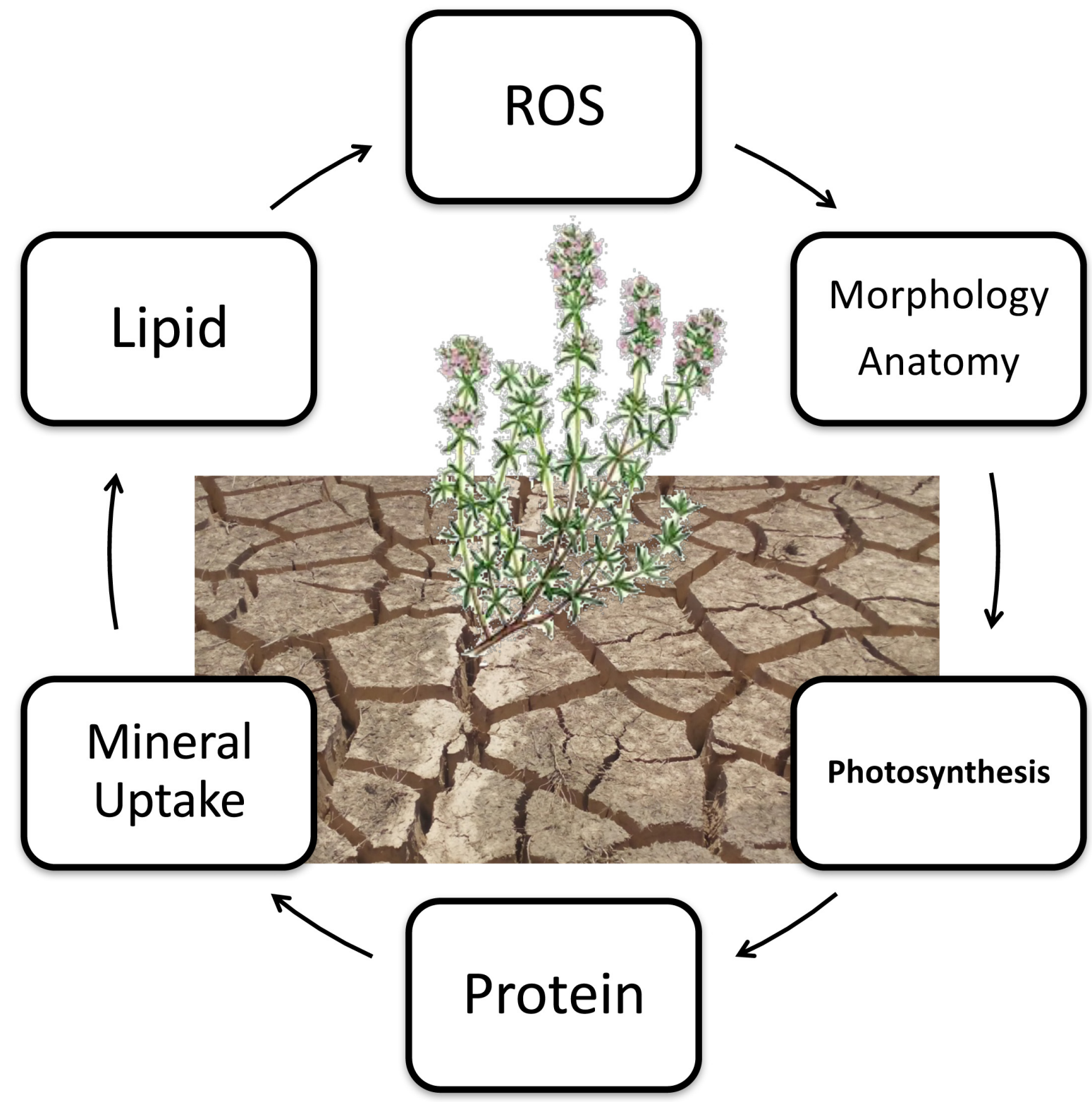

Figure 1. Effects of drought stress on plants. Reducing available water in the plant environment, declines water content, water potential and turgor pressure. This condition affects lipids, proteins, photosynthesis, mineral uptake, morphology and anatomy and ROS. 
In morphology, effects are on growth and establishment at early stages of plant growth. It is because of decrease in elongation and expansion growth (Kusaka et al. 2005, Hong-Bo et al. 2008). Numerous studies have reported a reduction in height and stem length of different plants in response to drought (Manivannan et al. 2007, Petropoulos et al. 2008a, Sankar et al. 2008). Several studies established a decline in leaf area growth due to drought in different plants such as poplar, soybean, maize and sunflower (Sacks et al. 1997, Wullschleger et al. 2005, Manivannan et al. 2007, Farooq et al. 2009). Some studies showed drought stress significantly increased root growth (Jaleel et al. 2008) but in some studies drought decreased root growth (Wullschleger et al. 2005, Vandoorne et al. 2012). Arguably the most important effect is on plant fresh and dry matter under drought stress, which is economically important. It has been shown that fresh and dry weight of plants decreased due to drought in several studies (Petropoulos et al. 2008a, Farooq et al. 2009). Drought affects plant growth via some physiological and biochemical processes, such as declining photosynthesis, respiration, translocation, ion uptake, carbohydrates, nutrient metabolism and growth promoters (Jaleel et al. 2008, Farooq et al. 2009). Physiological effects start when the available water in soil decreases, and then the water potential is getting lower than that in the roots (Sunkar 2010). In the early stages of dehydration, photosynthesis decreases due to $\mathrm{CO}_{2}$ shortage, because of stomata closure (Chaves 1991). Even though it is still arguable which $\mathrm{CO}_{2}$ shortage is the main reason of photosynthesis declining. This maybe is due to difference drought treatment in different stages, species and leaf age (Chaves et al. 2003).

Plants have different strategies to confront water limitation, which can be classified into three main categories (Figure2). See (Bray 2007) and (Verslues et al. 2006) for more details.

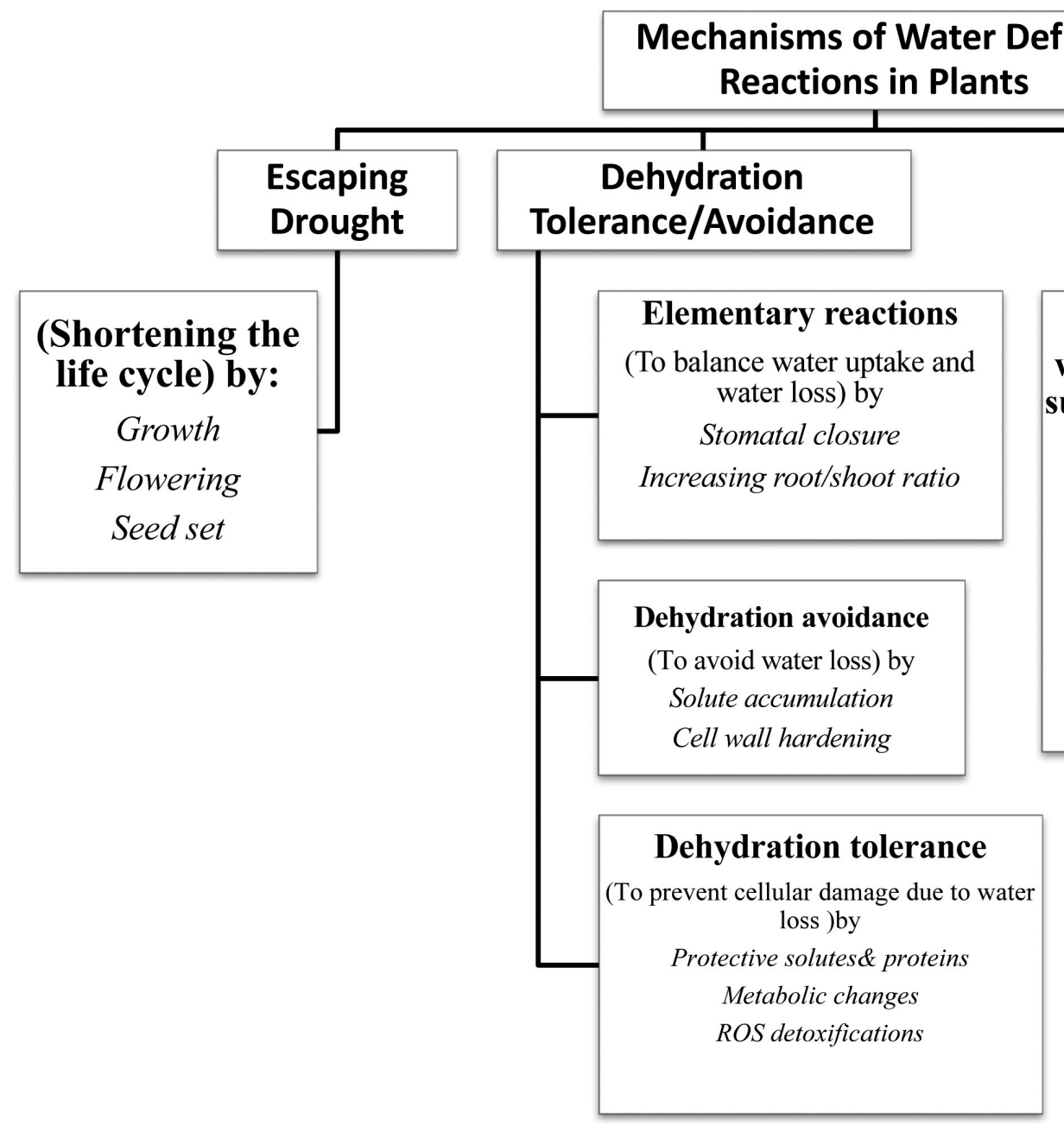

Figure 2. Main mechanisms of plant reactions to water deficit. Possible processes of each mechanism have been indicated in the boxes. 
Plants and how they react to water deficit can be summarised in three ways i.e. escaping drought, dehydration tolerance/avoidance and desiccation tolerance. In some references, drought resistance is described as the adaptation of plant involving drought avoidance, drought tolerance, drought escape and drought recovery (Fang \& Xiong 2015). Since, drought tolerance is characterized by the capability of plants to grow satisfactorily under water deficit condition (Turner 1979).

Escaping the drought is shortening the life cycle mainly in reproductive phase and desiccation tolerance can be performed in both reproductive and vegetative phases of some specific plants. Tolerance to an environmental factor could be defined as the fitness response of a plant to a diverse concentration of that element. Accordingly, water stress tolerance means the ability to retain the fitness under the water deficit condition (Simms 2000). Hence, a more tolerant genotype minimizes fitness losses in water deficit conditions from that attained in benign water conditions with respect to less tolerant or sensitive genotypes. Dehydration avoidance/tolerance mostly happens in crop plants in vegetative phase. Desiccation tolerance is observed in a specific category of the plant kingdom called resurrection plants.

Water supply affects almost all plant processes directly or indirectly (Akıncı 1997), hence water deficit stress due to reduction of available water will affect plants in various ways. Even though certain plants have evolved specific adaptive mechanisms to alleviate adverse effects of water deficit stress, there are some common metabolic adaptations observed in diverse economical plants. It seems these results regarding key metabolites and identified mechanisms could be used in plant breeding programs particularly for improving stress tolerance in economical plants. Given the importance of shortening the plant breeding procedures to release new improved varieties, such compounds can serve as biomarker. In this way, selection of superior individuals in segregation generations could be facilitated. Therefore, it is necessary to recognise plant adaptive mechanisms and differentiate avoidance and tolerance strategies with the aim to understand the tolerance mechanisms at the metabolite level.

Drought escape. Basically the plant shortens the life cycle in this way; two outstanding examples are converting to flowering phase when water is limited at late season and also germination at early season growth. In this strategy the plant does not invest too much in the metabolic pathways against stress, instead, it maximizes the pathways for fast growth to overcome the crisis (Verslues \& Juenger 2011).

Dehydration avoidance. As the direction of water movement is from higher to lower water potential, in dehydrated soil, roots will lose water. The first strategy of the plant is dehydration avoidance by keeping the balance between water loss from the roots and water uptake. In other words, plants can avoid or postpone the water deficit stress for a short period of time using the following mechanisms: stomatal closure, increasing root/shoot ratio (Pallardy 2008), morphological changes in roots and leaves, accumulation of solutes and cell wall hardening (Verslues et al. 2006).

Several morphological developments have been demonstrated previously to be correlated with avoidance mechanisms through minimizing the water loss. These modifications include dense stomata (Larcher 2003), longer roots with extensive branches (Passioura 1983, Arndt 2000), rolling leaf (Schwabe \& Lionakis 1996), dense leaf pubescence (Karabourniotis \& Bornman 1999, Liakoura et al. 1999, Bacelar et al. 2004), less intercellular space and smaller mesophyll cells (Bongi et al. 1987, Mediavilla et al. 2001), epicuticular wax layer and thick cuticle (Leon \& Bukovac 1978) and lignified tissue (Richardson \& Berlyn 2002). Root structure is associated with dehydration avoidance mechanisms. For instance, long roots with plentiful branches allow the plant to absorb more water sustainably and access larger soil volume (Passioura 1983, Arndt 2000). Moreover, water transport from the roots to the leaves through xylem in adaptive avoidance systems needs improved stomatal density and root conductivity (Tyree \& Ewers 1991, Jones 1992).

Dehydration tolerance. When low water potential persists, dehydration tolerance mechanisms contribute to prevent cellular damage by water loss (Verslues et al. 2006). Moreover, under severe drought stress conditions, dehydration tolerance is the final strategy that plants can employ to survive under drought stress conditions (Connor 2005). At genomic level, a large number of 
molecular events are altered in response to drought are classified into early responding within few minutes and hours and late responses which might take few days (Ramanjulu \& Bartels 2002). Early responses are including stress perception and signalling to provide initial protection. While, late responses initiate expression of many genes to contribute in stress acclimation consisting physiological, biochemical and morphological responses (Bhargava \& Sawant 2013). Stress perception is the first stage of drought stress response, to sense water deficit in the soil. The major components of stress sensing consists various kinds of cell surface receptors such as RLKs (Receptor-Like Kinases), G-Protein-Coupled Receptors (GPCRs), ion channel-linked receptors, and two-component histidine kinase receptors (Bhargava \& Sawant 2013, Parvathi \& Nataraja 2016). RLKs receptors like BR1 (Brassinosteroid Receptor 1) transduce stress signal by receptor internalization (Chae et al. 2009). While, Cre1 (cytokininresponse 1) as a two-component histidine kinase receptor act through phosphorilation pathway. Moreover, GPCRs sense stress via activation of enzymes phospholipase C/D (Tuteja \& Sopory 2008). For early responses of plant to water deficit condition, stress perception is followed by signal transduction which is operated by number of secondary messengers including ROS, $\mathrm{Ca}^{2+}$, nitric oxide (NO), cAMP (Cyclic Adenosin MonoPhosphate), phosphoprotein (serine/threonine phosphatases), phospholipids like phosphoinositides(Bartels \& Sunkar 2005, Osakabe et al. 2013). When drought stress condition persists, late responses initiate, which is expression of set of genes responsible for osmolyte synthesis, LEA (Late Embryogenesis Abundant) proteins, aquaporins, signalling molecules and transcription factors (TFs) (Yang et al. 2010, Bhargava \& Sawant 2013).

In this review four main mechanisms of tolerance are described:

Osmotic adjustment.- While available water is decreasing in the soil, the accumulation of additional solutes and ions will occur in order to retain water content of the cell through reducing the osmotic potential (Taiz \& Zeiger 2002, Fang \& Xiong 2015). This mechanism is called osmotic adjustment, and these solutes are known as compatible solutes, because with their increase, plant metabolism is not disturbed and they are not toxic even in higher concentrations (Yancey et al. 1982, Slama et al. 2015). When osmotic potential decreases due to osmolyte accumulation, water potential will decrease (Zhang et al. 1999, Verslues et al. 2006). Osmotic pressure $(\pi)$ is a property of a solution due to the presence of solutes (Nobel 1999). Osmotic pressure rises by increasing (accumulating) the solutes. In literature, osmotic potential $\left(\Psi_{\pi}\right)$ is used instead of osmotic pressure, since for plant-water relation calculations researchers use water potential $(\Psi)$. Osmotic potential $\left(\Psi_{\pi}\right)$ is negative sign of osmotic pressure, i.e. $\Psi_{\pi}=-\pi$. Therefore, when solute concentration increases, osmotic pressure will increase while osmotic potential will decrease. This mechanism is shown in Figure 3.

Water always flows from higher water potential to lower water potential.- Under normal conditions, water moves into the cell due to the difference in water potential of outside (-1Bar) from inside (-3 Bar). Under drought condition, two possible responses of cell are presented. Without osmotic adjustment, plasmolysis will be happened. If cell activates osmotic adjustment mechanism, both turgor pressure and osmotic potential will decrease. Therefore still water moves into the cell because of lower water potential.

$$
\Psi=\Psi_{\mathrm{p}}+\Psi_{\pi} / \text { Water Potential }=\text { Turgor Pressure }+ \text { Osmotic Potential }
$$

(Nobel, 1999)

Cell wall hardening or cell wall deformability is quantified by cell wall elastic modules, $\varepsilon$. When $\varepsilon$ is high, turgor pressure and $\Psi$ will decline, therefore this mechanism prevents water loss even without solute accumulation (Verslues et al. 2006).

Compatible solutes or, "osmolytes" or "osmo-protectants" known so far in plants are monosaccharides (fructose and glucose), sugar alcohols (mannitol, methylated inositol and pinitol), diand oligo-saccharides (sucrose, trehalose, raffinose and fructan), amino acids (proline, glycine betaine, alanine, betaine, proline betaine and citrulline) tertiary amines (ectoine; 1,4,5,6-tetrahydro-2-methyl-4-carboxylpyrimidine) and sulfonium compounds (choline o-sulfate, dimethyl sulfonium propironate) (Robinson \& Jones 1986, Pareek et al. 2010). These compounds contribute under drought stress through protecting cellular components (Chen \& Murata 2002), acting as osmoregulators with increasing osmotic pressure (Delauney \& Verma 1993), preventing loss of water from cells by keeping turgor pressure and water content high and also replacing water molecules in protein, nucleic acid structure because of their hydrophilic properties (Hoekstra 
Figure 3. Osmotic adjustment as a key mechanism of plant response to water deficit stress.

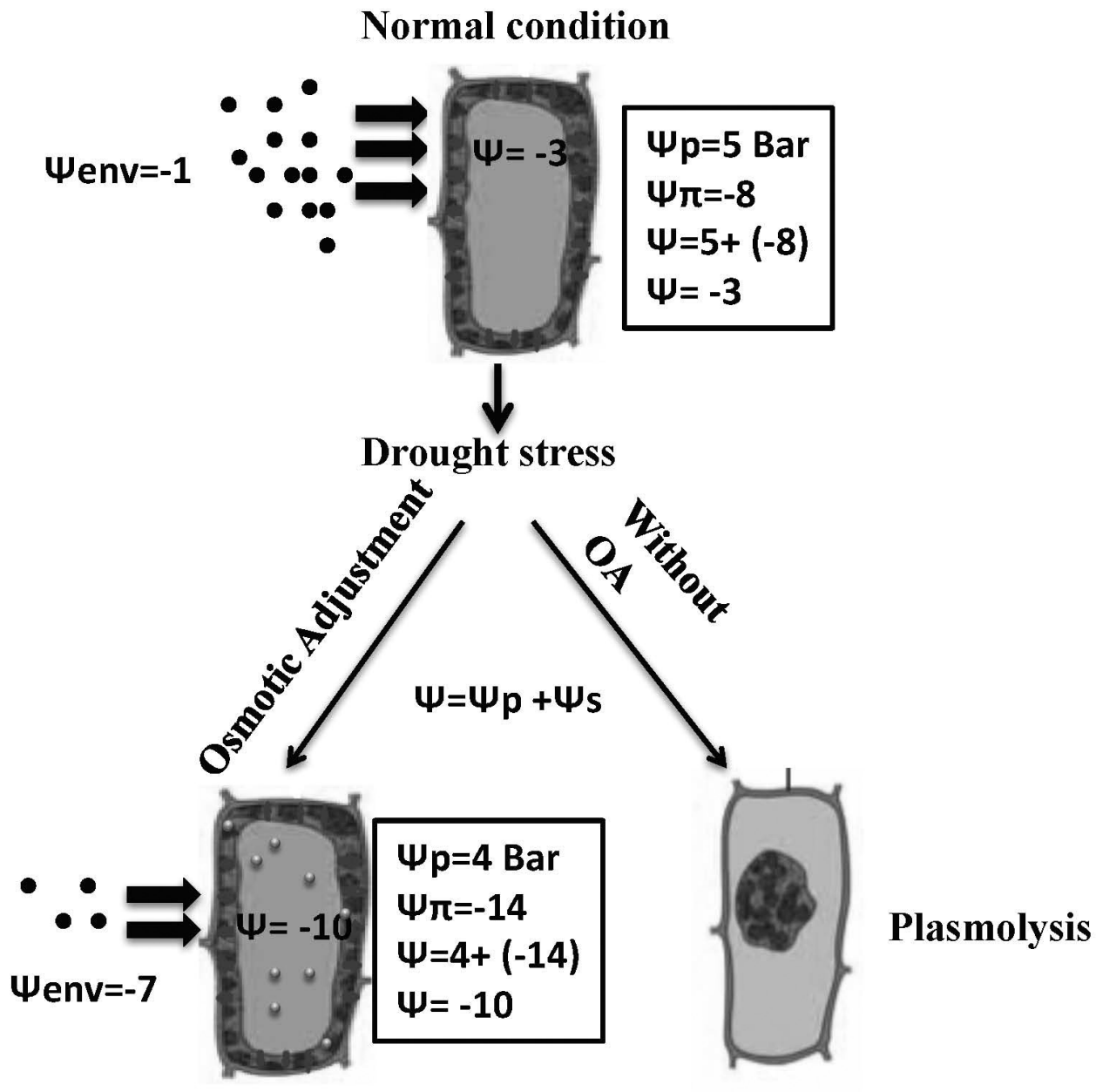

\section{Water deficit condition}

et al. 2001). In general, these metabolites stabilize enzymes, protect membranes and produce osmotic adjustments to keep the turgor pressure (Chaves et al. 2003).

Activation of antioxidant systems against oxidative stress damage.- Various environmental stresses such as drought, salinity, metal toxicity, cold and heat stress interrupt the normal cell metabolism (Maheshwari \& Dubey 2009) and this unfavourable condition leads to enhance production of Reactive Oxygen Species or ROS (Kele \& Ünyayar 2004). ROS or free radicals $\left(\mathrm{O}_{2} \cdot-, \cdot \mathrm{OH}, \mathrm{H}_{2} \mathrm{O}_{2},{ }^{1} \mathrm{O}_{2}\right)$ are produced in cellular compartments as a by-product of various biochemical reactions or in chloroplasts, mitochondria and plasma membranes by exposing to high energy electron leak from electron transport activities (Foyer et al. 1994, Foyer 1997, Luis et al. 2006, Blokhina \& Fagerstedt 2010, Heyno et al. 2011). These toxic molecules damage cells by oxidation of vital macromolecules such as proteins, membrane lipids, DNA, pigments and nucleic acids (Dat et al. 2000, Maheshwari \& Dubey 2009). Various studies have established the enhancement of ROS under osmotic stress conditions (Serrato et al. 2004, Borsani et al. 2005, Miao et al. 2006, Abbasi et al. 2007). In accordance, plants are equipped with complex defence mechanisms using enzymatic and non-enzymatic antioxidants to mitigate oxidative damages caused by ROS (Dat et al. 2000). Enzymatic antioxidants involve superoxide dismutase (SOD), catalase (CAT), guaiacol peroxidase (GPX), enzymes of ascorbate- glutathione cycle (AsAGSH) cycle such as ascorbate peroxidise (APX), monodehydroascorbate reductase (MDHAR), dehydroascorbate reductase (DHAR), and glutathione reductase (GR) (Noctor \& Foyer 1998). Non-enzymatic antioxidants are ascorbate (AsA), glutathione (GSH), carotenoids, tocopherols, and phenolics (Sharma et al. 2012). Strong correlation has been reported between stress tolerance and higher concentrations of antioxidants (Zaefyzadeh et al. 2009, Chen et al. 2011). Many 
studies on crop plants including sorghum, rice and rapeseed confirmed that tolerant cultivars as compared to sensitive ones, exhibited up-regulation of antioxidant gene network products, to protect the plant subjected to drought stress. Hence, in tolerant plants ROS accumulation were lower than sensitive genotypes due to higher activity of antioxidant systems (Jagtap \& Bhargava 1995, Abedi \& Pakniyat 2010).

$\mathrm{ABA}$ and its physiological role in drought stress response.- In response to unfavourable environments such as drought, plants employ ABA (abscisic acid) to activate adaptive metabolic responses (Kusaka et al. 2005). In addition, ABA serves as a plant development optimizer (Cheng et al. 2002) and seed development regulator (Specht et al. 2001). ABA chemically belongs to sesquiterpenes where 9'-cis-epoxycarotenoid dioxygenase (NCED) produces C15 (xanthoxin) from cleavage of 9'-cis-neoxanthin and 9'-cis-violaxanthin (Nambara \& Marion-Poll 2005). Then, ABA aldehyde converts xanthoxin to ABA (Sankar et al. 2007). Obviously water status is a stimulus of ABA formation (Petropoulos et al. 2008b), but there is little knowledge on signalling cascades leading to ABA induction. However, there is a different NCED gene family, which each gene activates the specific role for ABA (Sunkar 2010). For instance, AtNCED3 in Arabidopsis induces ABA in response to drought stress and AtNCED6 and AtNCED9 play a role in seed dormancy and germination (Verslues et al. 2006). ABA activity results from synthesis, degradation and also translocation of ABA (Sankar et al. 2007). However, major roles of ABA in water deficit responses can be summarized as: causing stomata closure through guard cell regulation (Imber \& Tal 1970, Zhang et al. 1999) and also maintaining sustainable water uptake during water stress by continuous root growth through activation of various hormonal signalling pathways. In detail, stomatal closure is mediated by phospholipase activity and hyperpolarisation of membrane $\mathrm{Ca}^{2+}$ channels and tonoplast $\mathrm{K}^{+}$channels of the guard cells (MacRobbie 2000). Moreover, increase in root growth and decrease in shoot growth is due to low concentration of ABA in the latter and more ABA accumulation in the former; because ABA prevents the inhibition property of ethylene (Sharp 2002, Sharp \& LeNoble 2002). In general, $\mathrm{ABA}$ enhances dehydration tolerance through induction of genes encoding tolerance proteins in most of the cells (Kusaka et al. 2005).

In Arabidopsis it has been shown that after osmotic stress which has followed water deficit, a transmembrane histidine kinase known as 'osmometer' called AtHK1 acts as receptor for water deficit (Posas et al. 1996). After the first stage of sensing, drought response directs to ABAdependent and ABA-independent pathways. ABA-dependent pathways are activated following the accumulation of $\mathrm{ABA}$, and leading to expression of two kinds of stress related genes namely functional and regulatory. But ABA-independent pathways are not related to each other and seem there is some cross-talk between them (Chaves et al. 2003).

Other mechanisms of dehydration tolerance.- Membrane proteins such as aquaporins (AQP) can transport water, solutes and gases through membranes or even throughout the plant (Bray et al. 2000, Maurel et al. 2015). AQPs are divided into five groups: plasma-membrane intrinsic proteins (PIPs), tonoplast-intrinsic proteins (TIPs), and nodulin-26-like major-intrinsic proteins (NLMs), the small basic intrinsic proteins (SIPs) and (XIPs) the uncategorized intrinsic proteins (Maurel et al. 2015). The XIPs were found in some plant species more recently. Under water limitation condition, AQPs modulate the water balance for the whole plant by passive water transport through membrane (Maurel et al. 2008). These membrane proteins form channels to pass water easily through the plasma (Kammerloher et al. 1994) and vacuolar membranes(Höfte et al. 1992). Therefore, under dehydration conditions, these membrane-associated transporters may serve as water movement facilitators (Bray et al. 2000).

Key plant products involved in water deficit response. Many compounds contribute to adaptive response to drought stress (acclimation process). These compounds belong to three groups: the first group is all major compounds with a key role in adaptive response such as osmolytes (Slama et al. 2015). The second group is consisting of by-products of stress responses generated through perturbation of normal metabolism such as ROS (Gupta \& Igamberdiev 2014). Third group are signalling molecules which regulate adaptive responses such as salicylic acid (Mittler 2002, Mittler et al. 2004). However, to explain the role of adaptive compounds we had to classify them into major classes such as lipids, compatible solutes, proteins and secondary metabolites. 
Lipids.- Lipids are main compounds of membranes and water stress affects lipids and embedded proteins (Kuiper 1985). Likewise, function and structure of membranes as well as enzyme activity and transport capacity are affected by the physical state and composition of lipids (Gronewald et al. 1982, Kuiper 1985, Whitman \& Travis 1985).

Main lipids of membranes are phospholipids (PL mostly in mitochondrial and plasma membrane) and glycolipids (GL mostly in chloroplast membrane). Another form of lipids in plants is fats and oils which belong to triglycerides (TGL) (Taiz \& Zeiger 2002). As an example of fatty acid composition in leaves, six classes were detected in bent grass leaves including palmitic acid (16:0), palmitoleic acid (16:1), stearic acid (18:0), oleic acid (18:1), linoleic acid (18:2) and linolenic acid (18:3) (Liu \& Huang 2004). There are various studies on stress effects on plant lipids (Douglas \& Paleg 1981, Pham Thi et al. 1982, Anh et al. 1985, Liljenberg \& Kates 1985, Pham Thi et al. 1987, Navari-Izzo et al. 1989, Navari-Izzo et al. 1990, Navari-Izzo et al. 1993). Some investigations showed that water stress reduced PL and GL in cotton (Wilson et al. 1987), wheat, barley (Chetal et al. 1981), sunflower (Navari-Izzo et al. 1990), but some of the studies indicated an increase of PL in wheat (Kameli \& Lösel 1995), total lipid increase in alfalfa (Akınc1 \& Lösel 2012), and free fatty acid increase in wheat (Quartacci \& Navari-Izzo 1992). In general, studies demonstrated that long water deficit causes decreasing PLs and GLs and linoleic acid contents but increasing tricylglycerols in leaf tissue. Likewise, previous investigations showed that water deficit inhibits biosynthesis of polyunsaturated fatty acids which leads to reduced fatty acid unsaturation (Anh et al. 1985, Martin et al. 1986, Navari-Izzo et al. 1989). One of the tolerance mechanisms in response to drought stress is modification in leaf cell membrane lipid composition (Turner \& Jones 1980, Ferrari-Iliou et al. 1984, Anh et al. 1985, Quartacci \& Navari-Izzo 1992). These modifications include decreasing polar lipid contents and also polyunsaturated fatty acids, but particularly the major leaf glycolipid (MGDG or MonoGalactosyl DiacylGlycerol) (Chetal et al. 1981, Pham Thi et al. 1982). These alterations are likely due to increased lipolytic performance, lipid biosynthesis inhibition (Anh et al. 1985), and generating of scavenging free radicals (Ferrari-Iliou et al. 1992). Previous studies established that the extent of these modifications in drought tolerant plants is less than sensitive ones because their cell membrane is more stable (Pham Thi et al. 1990).

Compatible solutes.- As described in previous sections, compatible solutes contribute to the well-known tolerance mechanism called osmotic adjustment. These metabolites ("osmolytes" or "osmo-protectants") are monosaccharides (fructose and glucose), di- and oligo-saccharides (sucrose, trehalose, raffinose and fructan), sugar alcohols or polyols (mannitol, inositol, methylated inositol, glycerol and pinitol), amino acids (proline,citrulline, pipecolic acid), betaines (glycine betaine, alanine betaine, proline betaine, hydroxyproline betaine), tertiary amines (ectoine; 1,4,5,6-tetrahydro-2-methyl-4-carboxylpyrimidine) and sulphonium compounds (choline o-sulfate, dimethyl sulfoniumpropironate-DMSP)(Robinson \& Jones 1986, Pareek et al. 2010, Slama et al. 2015). Nevertheless, enhanced accumulation of mentioned osmolytes has been reported in various plants exposed to abiotic stresses, but threshold level and diversity of the osmolytes depend on the species and environmental condition (Szabados et al. 2011). In the other hand, some species accumulate only some specific kinds of osmolytes, not all the kinds. For instance, sugar accumulation has been observed in monocots rather than dicots. Likewise, glycine betain is less accumulated in grasses (Slama et al. 2015).

Proteins.- Drought stress induces a large number of genes encoding biosynthesis of low molecular weight proteins such as LEA proteins (Late Embryogenesis Abundant), dehydrins and molecular chaperons (Ingram \& Bartels 1996, Mahajan \& Tuteja 2005). Dehydrins were observed in response to various abiotic stresses including drought, but its detailed function is not well understood (Cellier et al. 2000). LEAs have multiple tasks ranging from maturity in seeds to protection of membrane structure, stabilizing enzymes and promoting ion sequestration in vegetative organs (Close 1997, Garay-Arroyo et al. 2000, Fang \& Xiong 2015). Another class of proteins known as molecular chaperones (or originally known as HSP: Heat Shock proteins) has been reported under abiotic stress conditions such as drought (Alamillo et al. 1995, Alpert \& Oliver 2002). Much evidence confirms that HSPs act in protein refolding, stabilizing proteins and membranes under stress conditions (Wang et al. 2004). In this way, HSPs protects other proteins from denaturation during drought stress (Gorantla et al. 2007). Particularly small HSP or sHSPs (Hendrick \& Hartl 
1995, Hong \& Vierling 2000), one of the five major families of molecular chaperones/HSPs, bind to partially folded or denatured substrate proteins and allow them to fold correctly (Sun et al. 2002). Some sHSPs gene expression and protein synthesis up-regulated with stress in sunflower (Coca et al. 1996). Role of HSPs in tolerance mechanism been confirmed while up-regulation of a specific HSP observed in tolerant varieties of wheat compare to down regulation in sensitive varieties under drought stress conditions (Hajheidari et al. 2005).

Secondary metabolites.- Plants in addition to primary metabolites (proteins, carbohydrates and fatty acids) produce a large diversity of compounds known as secondary metabolites (Frey et al. 1999). To date, 200,000 diverse compounds have been identified as secondary metabolites (Schwab 2003) which are classified into three major groups namely alkaloids, isoprenoids and phenylpropanoids (Frey et al. 1999). Apparently secondary metabolites are not involved directly in plant growth and development, but they have specific roles in adaptation and defence against biotic and abiotic stresses (Jaillais \& Chory 2010). According to definition, secondary metabolites are produced from primary metabolites and certain secondary metabolites (SMs) are synthesized in specific genera or species. Moreover, SMs mostly accumulate in high quantities in the vacuoles in a glycosidic form or in specific structures such as trichoms, ducts, canals and lacticifers (Santner \& Estelle 2009).

Secondary metabolites can serve as protective agent or antioxidants under unfavourable environments such as drought. For example, in bean and tobacco under diverse abiotic stress conditions, high concentrations of polyamines and phenyl amides have been observed (Jenks et al. 2007). In general, high accumulation of flavonoids and phenolic acids (Hirt \& Shinozaki 2003), polyamines (Alpert 2006, Pathak et al. 2014) and anthocyanin (Alpert 2005) under abiotic stresses including drought has been reported. Polyamines (PAs) as nitrogen-containing compounds commonly consist putrescine (Put), spermine (Spm) and spermidine (Spd)(Alcázar et al. 2010). These low molecular weight compounds involved in osmotic balance, scavenging ROS and stabilizing macromolecule structure such as DNA, RNA, membrane proteins and lipids (Liu et al. 2007, Takahashi \& Kakehi 2010, Hussain et al. 2011). Moreover, they act as regulatory element in developmental, physiological and biochemical events including biotic and abiotic stress response (Malmberg et al. 1998, Pathak et al. 2014). Nevertheless the exact mechanism of PAs incorporation into stress response is less known to date (Pathak et al. 2014), but increasing PAs concentration during drought stress might be due to either de novo biosynthesis or reduced degradation (Liu et al. 2007). PAs alteration under stress condition might be affected by sensitive/tolerant type plant, duration \& intensity of stress and developmental stage of tissue. In general, several reports consistently confirmed an increase in Spd and Spm for tolerant cultivar compared with sensitive cultivars of wheat (Liu et al. 2004), groundnut (Vakharia et al. 2003) and tomato (Santa-Cruz et al. 1998). While, in these experiments, sensitive cultivars exhibited elevation in Put level under stress condition. Correspondently, transgenic plants with increasing accumulation of Put, Spd and Spm enhanced tolerance to drought stress (Capell et al. 2004, Bassie et al. 2008).

Previous works established the key role of ABA, SA (Salicylic acid), JA (Jasmonic acid) and polyamines in biotic and abiotic responses (McCarty et al. 1989, Pathak et al. 2014). Jasmonates consisting of methyl jasmonate and jasmonic acid are correlated to the accumulation of defence systems, i.e. secondary metabolites such as alakaloids, terpenoids, coumarines and phenolic phytoalexins (van der Fits \& Memelink 2000). Recently, the contribution of various secondary metabolites in enhancing abiotic stress tolerance through functioning as antioxidants has been proved. These compound are saponin (Chan et al. 2010), melotonine (Tan et al. 2007), and serotonine (Anjum et al. 2008).

\section{Conclusions}

Tolerant plants accumulate or maintain high levels of particular metabolites to cope with unfavourable conditions. Reviewed compounds could be used as biochemical indicators in breeding programs to improve drought stress tolerance.

Exogenous application of compounds involved in adaptive responses to drought stress might alleviate adverse effects of stress. Whereas previous works support the enhancement of water 
deficit stress tolerance by foliar application of major compounds such as glycine betaine, kinetin, nitric oxide and salicylic acid (Rao et al. 2012), it is necessary further experiments to examine the influence of key metabolites (or generally compounds) in the alleviation of drought stress negative effects. Foliar applying (spraying or fumigating) of the selected metabolites in the form of available commercial products might be an alternative method to enhance sensitive plants productivity under drought stress conditions.

\section{Acknowledgments}

The author is very grateful to Dr. Jeremy Pritchard, Dr. Youness Saidi, Dr. Juliet coats and Prof. Brian Ford-Lloyd for their helpful comments. I would like to thank my home institute (AREOAgricultural Research and Education Organization, Iran) for generously providing financial funding for this research.

\section{Literature cited}

Abbasi A-R, Hajirezaei M, Hofius D, Sonnewald U, Voll LM. 2007. Specific roles of $\alpha$-and $\gamma$-tocopherol in abiotic stress responses of transgenic tobacco. Plant Physiology 143:1720-1738.

Abedi T, Pakniyat H. 2010. Antioxidant enzyme changes in response to drought stress in ten cultivars of oilseed rape (Brassica napus L.). Czech Journal of Genetics and Plant Breeding 46:27-34.

Akınc1 S. 1997. Physiological responses to water stress by Cucumis sativus L. and related species. $\mathrm{PhD}$ Thesis, University of Sheffield,Sheffield.

Akıncı Ş, Lösel DM. 2012. Plant Water-Stress Response Mechanisms. In: Rahman, IMM, Hasegawa, H. eds. Water Stress, Croatia: intechweb.org, 15-42..

Alamillo J, Almoguera C, Bartels D, Jordano J. 1995. Constitutive expression of small heat shock proteins in vegetative tissues of the resurrection plant Craterostigma plantagineum. Plant Molecular Biology 29:1093-1099.

Alcázar R, Altabella T, Marco F, Bortolotti C, Reymond M, Koncz C, Carrasco P, Tiburcio AF. 2010. Polyamines: molecules with regulatory functions in plant abiotic stress tolerance. Planta 231:1237-1249.

Alpert P, Oliver MJ. 2002. Drying Without Dying. In: Black M, Pritchard H,eds. Desiccation and survival in plants: drying without dying, Wallingford: CABI Publishing, 3-46

Alpert P. 2005. The limits and frontiers of desiccation-tolerant life. Integrative and Comparative Biology 45:685-695.

Alpert P. 2006. Constraints of tolerance: why are desiccation-tolerant organisms so small or rare? Journal of Experimental Biology 209:1575-1584.

Anh TPT, Borrel-Flood C, da Silva JV, Justin AM, Mazliak P. 1985. Effects of water stress on lipid metabolism in cotton leaves. Phytochemistry 24:723-727.

Anjum NA, Umar S, Iqbal M, Khan NA. 2008. Growth characteristics and antioxidant metabolism of moongbean genotypes differing in photosynthetic capacity subjected to water deficit stress. Journal of Plant Interactions 3: 127-136.

Arndt SK. 2000. Mechanisms of drought resistance in the tropical fruit tree Ziziphus, PhD Thesis, Vienna University.

Bacelar EA, Correia CM, Moutinho-Pereira JM, Gonçalves BC, Lopes JI, Torres-Pereira JM. 2004. Sclerophylly and leaf anatomical traits of five field-grown olive cultivars growing under drought conditions. Tree physiology 24:233-239.

Bartels D, Sunkar R. 2005. Drought and salt tolerance in plants. Critical Reviews in Plant Sciences 24:23-58.

Bassie L, Zhu C, Romagosa I, Christou P, Capell T. 2008. Transgenic wheat plants expressing an oat arginine decarboxylase cDNA exhibit increases in polyamine content in vegetative tissue and seeds. Molecular Breeding 22:39-50.

Bhargava S, Sawant K. 2013. Drought stress adaptation: metabolic adjustment and regulation of gene expression. Plant Breeding 132:21-32.

Blokhina O, Fagerstedt KV. 2010. Reactive oxygen species and nitric oxide in plant mitochondria: origin and redundant regulatory systems. Physiologia Plantarum 138:447-462.

Bongi G, Mencuccini M, Fontanazza G. 1987. Photosynthesis of olive leaves: effect of light flux density, leaf age, temperature, peltates, and $\mathrm{H}_{2} \mathrm{O}$ vapor pressure deficit on gas exchange. Journal of the American Society for Horticultural Science 112:143-148.

Borsani O, Zhu J, Verslues PE, Sunkar R, Zhu J-K. 2005. Endogenous siRNAs Derived from a Pair of Natural cis-Antisense Transcripts Regulate Salt Tolerance in Arabidopsis. Cell 123:1279-1291. 
Bray EA, Bailey-Serres J, Weretilnyk E. 2000. Responses to abiotic stresses. In: Gruissem, W. ed. Biochemistry and Molecular Biology of Plants, American Society of Plant Physiologists, 1158-1203.

Bray EA. 2007. Plant Response to Water-deficit Stress. eLS. Chicago: John Wiley \& Sons, Ltd.

Capell T, Bassie L, Christou P. 2004. Modulation of the polyamine biosynthetic pathway in transgenic rice confers tolerance to drought stress. Proceedings of the National Academy of Sciences of the United States of America 101:9909-9914.

Cellier F, Conéjéro G, Casse F. 2000. Dehydrin transcript fluctuations during a day/night cycle in droughtstressed sunflower. Journal of experimental Botany 51:299-304.

Chae L, Sudat S, Dudoit S, Zhu T, Luan S. 2009. Diverse transcriptional programs associated with environmental stress and hormones in the Arabidopsis receptor-like kinase gene family. Molecular Plant 2:84-107.

Chan LK, Koay SS, Boey PL, Bhatt A. 2010. Effects of abiotic stress on biomass and anthocyanin production in cell cultures of Melastoma malabathricum. Biological Researchs 43:127-135.

Chaves MM. 1991. Effects of water deficits on carbon assimilation. Journal of experimental Botany 42:1-16.

Chaves MM, Maroco JP, Pereira JS. 2003. Understanding plant responses to drought - from genes to the whole plant. Functional Plant Biology 30:239-264.

Chen Q, Zhang M, Shen S. 2011. Effect of salt on malondialdehyde and antioxidant enzymes in seedling roots of Jerusalem artichoke (Helianthus tuberosus L.). Acta Physiologiae Plantarum 33:273-278.

Chen THH, Murata N. 2002. Enhancement of tolerance of abiotic stress by metabolic engineering of betaines and other compatible solutes. Current opinion in plant biology 5:250-257.

Cheng W-H, Endo A, Zhou L, Penney J, Chen H-C, Arroyo A, Leon P, Nambara E, Asami Asami T, Seo M, Koshiba T and Sheen J. 2002. A unique short-chain dehydrogenase/reductase in Arabidopsis glucose signaling and abscisic acid biosynthesis and functions. The Plant Cell 14:2723-2743.

Chetal S, Wagle DS, Nainawatee HS. 1981. Glycolipid changes in wheat and barley chloroplast under water stress. Plant Science Letters 20:225-230.

Close TJ. 1997. Dehydrins: A commonality in the response of plants to dehydration and low temperature. Physiologia Plantarum 100:291-296.

Coca MA, Almoguera C, Thomas TL, Jordano J. 1996. Differential regulation of small heat-shock genes in plants: analysis of a water-stress-inducible and developmentally activated sunflower promoter. Plant Molecular Biology 31:863-876.

Connor DJ. 2005. Adaptation of olive (Olea europaea L.) to water-limited environments. Crop and Pasture Science 56:1181-1189.

Dat J, Vandenabeele S, Vranova E, Van Montagu M, Inzé D, Van Breusegem F. 2000. Dual action of the active oxygen species during plant stress responses. Cellular and Molecular Life Sciences 57:779-795.

Delauney AJ, Verma DPS. 1993. Proline Biosynthesis and Osmoregulation in Plants. Plant Journal 4:215-223.

Del rio LA, Sandalio LM, Corpas FJ, Palma JM, Barroso JB. 2006. Reactive oxygen species and reactive nitrogen species in peroxisomes. Production, scavenging, and role in cell signaling. Plant Physiology 141:330-335.

Douglas TJ, Paleg Lg. 1981. Lipid composition of Zea mays seedlings and water stress-induced changes. Journal of Experimental Botany 32:499-508.

Fang Y, Xiong L. 2015. General mechanisms of drought response and their application in drought resistance improvement in plants. Cellular and Molecular Life Sciences 72:673-689.

Farooq M, Wahid A, Kobayashi N, Fujita D, Basra SMA. 2009. Plant drought stress: effects, mechanisms and management. Agronomy for Sustainable Development 29:185-212.

Ferrari-Iliou R, Pham Thi A, Mazlik P, da Silva JV. 1992. Effets de la peroxydation des lipides membranaires sur la physiologie des végétaux. L'Année Biologique 31:1-23.

Ferrari-Iliou R, Pham Thi A, da Silva JV. 1984. Effect of water stress on the lipid and fatty acid composition of cotton (Gossypium hirsutum) chloroplasts. Physiologia Plantarium 62:219-224.

Foyer CH, Harbinson J, Mullineaux PM. 1994. Oxygen metabolism and the regulation of photosynthetic electron transport. In: Foyer CH, Mullineaux PM (eds) Causes of photooxidative stress and amelioration of defense systems in plants. Boca Raton: CRC Press Inc, 1-42.

Foyer CH. 1997. Oxygen metabolism and electron transport in photosynthesis. Cold Spring Harbor Monograph Archive 34: 587-621.

Frey A, Audran C, Marin E, Sotta B, Marion-Poll A. 1999. Engineering seed dormancy by the modification of zeaxanthin epoxidase gene expression. Plant Molecular Biology 39:1267-1274.

Garay-Arroyo A, Colmenero-Flores JM, Garciarrubio A, Covarrubias AA. 2000. Highly hydrophilic proteins in prokaryotes and eukaryotes are common during conditions of water deficit. Journal of Biological Chemistry 275:5668-5674.

Gorantla M, Babu P, Lachagari VR, Reddy A, Wusirika R, Bennetzen JL, Reddy AR. 2007. Identification of stress-responsive genes in an indica rice (Oryza sativa L.) using ESTs generated from droughtstressed seedlings. Journal of Experimental Botany 58:253-265. 
Gronewald JW, Aboukhalil W, Weber EJ, Hanson JB. 1982. Lipid-Composition of a Plasma-Membrane Enriched Fraction of Maize Roots. Phytochemistry 21:859-862.

Gupta KJ, Igamberdiev AU.( Eds). 2015. Reactive Oxygen and Nitrogen Species Signaling and Communication in Plants: Springer International Publishing.

Hajheidari M, Abdollahian-Noghabi M, Askari H, Heidari M, Sadeghian SY, Ober ES, Hosseini Salekdeh G. 2005. Proteome analysis of sugar beet leaves under drought stress. Proteomics 5:950-960.

Hendrick J, Hartl FU. 1995. The role of molecular chaperones in protein folding. The FASEB Journal 9:1559-1569.

Heyno E, Mary V, Schopfer P , Krieger-Liszkay A. 2011. Oxygen activation at the plasma membrane: relation between superoxide and hydroxyl radical production by isolated membranes. Planta 234:35-45.

Hirt H, Shinozaki K (Eds). 2004. Plant responses to abiotic stress. Berlin Heidelberg: Springer-Verlag

Hoekstra FA, Golovina EA, Buitink J. 2001. Mechanisms of plant desiccation tolerance. Trends in Plant Science 6:431-438.

Höfte H, Hubbard L, Reizer J, Ludevid D, Herman EM, Chrispeels M. 1992. Vegetative and seed-specific isoforms of a putative solute transporter in the tonoplast of Arabidopsis thaliana. Plant Physiology 99:561-570.

Hong S-W, Vierling E. 2000. Mutants of Arabidopsis thaliana defective in the acquisition of tolerance to high temperature stress. Proceedings of the National Academy of Sciences of the United States of America 97:4392-4397.

Hussain SS, Ali M, Ahmad M, Siddique KHH. 2011. Polyamines: natural and engineered abiotic and biotic stress tolerance in plants. Biotechnology Advances 29: 300-311.

Imber D, Tal M. 1970. Phenotypic reversion of flacca, a wilty mutant of tomato, by abscisic acid. Science 169:592-593.

Ingram J, Bartels D. 1996. The molecular basis of dehydration tolerance in plants. Annual Review of Plant Physiology and Plant Molecular Biology 47:377-403.

Jagtap V, Bhargava S. 1995. Variation in the Antioxidant Metabolism of Drought Tolerantand Drought Susceptible Varieties of Sorghum bicolor (L.) Moench. Exposed to High Light, Low Water and High Temperature Stress. Journal of Plant Physiology 145:195-197.

Jaillais Y, Chory J. 2010. Unraveling the paradoxes of plant hormone signaling integration. Nature Structural \& Molecular Biology 17:642-645.

Jaleel CA, Manivannan P, Sankar B, Kishorekumar A, Gopi R, Somasundaram R, Panneerselvam R. 2007. Water deficit stress mitigation by calcium chloride in Catharanthus roseus: effects on oxidative stress, proline metabolism and indole alkaloid accumulation. Colloids and Surfaces B-Biointerfaces 60:110-116.

Jaleel CA, Manivannan P, Lakshmanan GMA, Gomathinayagam M, Panneerselvam R. 2008. Alterations in morphological parameters and photosynthetic pigment responses of Catharanthus roseus under soil water deficits. Colloids and Surfaces B-Biointerfaces 61:298-303.

Jaleel CA, Manivannan P, Wahid A, Farooq M, Al-Juburi HJ, Somasundaram R, Panneerselvam R. 2009. Drought Stress in Plants: A Review on Morphological Characteristics and Pigments Composition. International Journal of Agriculture and Biology 11:100-105.

Jenks MA, Haegava PM, Jain SM (Eds). 2007. Advances in Molecular Breeding Toward Drought and Salt Tolerant Crops, New York: Springer.

Jones HG. 1992. Plants and Microclimate: A Quantitative Approach to Environmental Plant Physiology, Cambridge: Cambridge University Press.

Kameli A, Lösel DM. 1995. Contribution of carbohydrates and other solutes to osmotic adjustment in wheat leaves under water stress. Journal of plant physiology 145:363-366.

Kammerloher W, Fischer U, Piechottka GP, Schäffner AR. 1994. Water channels in the plant plasma membrane cloned by immunoselection from a mammalian expression system. The Plant Journal 6:187-199.

Karabourniotis G, Bornman JF. 1999. Penetration of UV-A, UV-B and blue light through the leaf trichome layers of two xeromorphic plants, olive and oak, measured by optical fibre microprobes. Physiologia Plantarum 105:655-661.

Kele Y, Ünyayar S. 2004. Responses of antioxidant defense system of Helianthus annuus to abscisic acid treatment under drought and waterlogging. Acta Physiologiae Plantarum 26:149-156.

Kramer PJ, Boyer JS. 1995. Water Relation s of Plants and Soils. San Diego:Academic Press.

Kuiper PJC. 1985. Environmental-Changes and Lipid-Metabolism of Higher-Plants. Physiologia Plantarum 64:118-122.

Kusaka M, Ohta M, Fujimura T. 2005. Contribution of inorganic components to osmotic adjustment and leaf folding for drought tolerance in pearl millet. Physiologia Plantarum 125:474-489.

Larcher W. 2003. Physiological plant ecology: ecophysiology and stress physiology of functional groups, New York: Springer. 
Leon JM, Bukovac MJ. 1978. Cuticle development and surface morphology of olive leaves w ith reference to penetration of foliar-applied chemicals. Journal of American Society for Horticultural Science 103:465-472.

Liakoura V, Stavrianakou S, Liakopoulos G, Karabourniotis G, Manetas Y. 1999. Effects of UV-B radiation on Olea europaea: comparisons between a greenhouse and a field experiment. Tree Physiology 19:905-908.

Liljenberg C, Kates M. 1985. Changes in lipid composition of oat root membranes as a function of waterdeficit stress. Canadian Journal of Biochemistry and Cell Biology 63:77-84.

Lisar SYS, Motafakkerazad R, Rahman MMI and Hossain MM. 2012. Water stress in plants: causes, effects and responses. In: Rahman M.M.I. and Hasegawa H., eds. Water Stress InTech Rijeka.

Liu HP, Dong BH, Zhang YY, Liu ZP, Liu YL. 2004. Relationship between osmotic stress and the levels of free, conjugated and bound polyamines in leaves of wheat seedlings. Plant Science 166:1261-1267.

Liu J-H, Kitashiba H, Wang J, Ban Y, Moriguchi T. 2007. Polyamines and their ability to provide environmental stress tolerance to plants. Plant Biotechnology 24:117-126.

Liu XZ, Huang BR. 2004. Changes in fatty acid composition and saturation in leaves and roots of creeping bentgrass exposed to high soil temperature. Journal of the American Society for Horticultural Science 129:795-801.

MacRobbie EAC. 2000. ABA activates multiple $\mathrm{Ca}^{2+}$ fluxes in stomatal guard cells, triggering vacuolar $\mathrm{K}^{+}\left(\mathrm{Rb}^{+}\right)$release. Proceedings of the National Academy of Sciences of the United States of America 97:12361-12368.

Mahajan S, Tuteja N. 2005. Cold, salinity and drought stresses: an overview. Archives of Biochemistry and Biophysics 444:139-158.

Maheshwari R, Dubey R. 2009. Nickel-induced oxidative stress and the role of antioxidant defence in rice seedlings. Plant Growth Regulation 59:37-49.

Malmberg RL, Watson MB, Galloway GL, Yu W. 1998. Molecular genetic analyses of plant polyamines. Critical Reviews in Plant Sciences 17:199-224.

Manivannan P, Jaleel CA, Sankar B, Kishorekumar A, Somasundaram R, Lakshmanan GMA, Panneerselvam R. 2007. Growth, biochemical modifications and proline metabolism in Helianthus annuus L. as induced by drought stress. Colloids and Surfaces B-Biointerfaces 59:141-149.

Martin BA, Schoper JB, Rinne RW. 1986. Changes in soybean (Glycine max [L.] Merr.) glycerolipids in response to water stress. Plant Physiology 81:798-801.

Maurel C, Verdoucq L, Luu D-T, Santoni V. 2008. Plant aquaporins: membrane channels with multiple integrated functions. Annual Review of Plant Biology 59:595-624.

Maurel C, Boursiac Y, Luu D-T, Santoni V, Shahzad Z, Verdoucq L. 2015. Aquaporins in plants. Physiological Reviews 95:1321-1358.

McCarty DR, Carson CB, Stinard PS , Robertson DS. 1989. Molecular analysis of viviparous-1: an abscisic acid-insensitive mutant of maize. The Plant Cell 1:523-532.

Mediavilla S, Escudero A, Heilmeier H. 2001. Internal leaf anatomy and photosynthetic resource-use efficiency: interspecific and intraspecific comparisons. Tree Physiology 21:251-259.

Miao Y, Lv D, Wang P, Wang X-C, Chen J, Miao C, Song C-P. 2006. An Arabidopsis glutathione peroxidase functions as both a redox transducer and a scavenger in abscisic acid and drought stress responses. The Plant Cell 18:2749-2766.

Mittler R. 2002. Oxidative stress, antioxidants and stress tolerance. Trends In Plant Science 7:405-410.

Mittler R, Vanderauwera S, Gollery M, Van Breusegem F. 2004. Reactive oxygen gene network of plants. Trends In Plant Science 9:490-498.

Moradi P. 2014. Use of metabolomics to study water deficit stress on the medicinal plant thyme. PhD Thesis, University of Birmingham, Birmingham.

Nambara E, Marion-Poll A. 2005. Abscisic acid biosynthesis and catabolism. Annual Review of Plant Biology 56:165-185.

Navari-Izzo F, Quartacci MF, Izzo R. 1989. Lipid changes in maize seedlings in response to field water deficits. Journal of experimental Botany 40:675-680.

Navari-Izzo F, Vangioni N, Quartacci MF. 1990. Lipids of soybean and sunflower seedlings grown under drought conditions. Phytochemistry 29:2119-2123.

Navari-Izzo F, Quartacci MF, Melfi D , Izzo R. 1993. Lipid composition of plasma membranes isolated from sunflower seedlings grown under water-stress. Physiologia Plantarium 87:508-514.

Nobel PS. 1999. Physicochemical and environmental plant physiology: Academic press. San Diego.

Noctor G, Foyer CH. 1998. Ascorbate and glutathione: keeping active oxygen under control. Annual Review of Plant Biology 49:249-279.

Osakabe Y, Yamaguchi-Shinozaki K, Shinozaki K, Tran L-SP. 2013. Sensing the environment: key roles of membrane-localized kinases in plant perception and response to abiotic stress. Journal of Experimental Botany 64:445-458. 
Pallardy SG. 2008. Physiology of woody plants: Academic Press. San Diego.

Pareek A, Sopory SK, Bohnert HJ, Govindjee (Eds). 2010. Abiotic Stress Adaptation in Plants Physiological, Molecular and Genomic Foundation: Springer..

Parvathi M, Nataraja KN. 2016. Emerging tools, concepts and ideas to track the modulator genes underlying plant drought adaptive traits: An overview. Plant Signaling \& Behavior 11:e1074370.

Passioura JB. 1983. Roots and drought resistance. Agricultural Water Management 7:265-280.

Pathak MR, Teixeira da Silva JA, Wani SH. 2014. Polyamines in response to abiotic stress tolerance through transgenic approaches. GM Crops \& Food 5:87-96.

Petropoulos SA, Daferera D, Polissiou MG, Passam HC. 2008a. The effect of water deficit stress on the growth, yield and composition of essential oils of parsley. Scientia Horticulturae 115:393-397.

Petropoulos SA, Daferera D, Polissiou MG, Passm HC. 2008b. The effect of water deficit stress on the growth, yield and composition of essential oils of parsley. Scientia Horticulturae 115:393-397.

Pham Thi A, Flood C, da Silva JV. 1982. Effects of water stress on lipid and fatty-acid composition of cotton leaves. In: Biochemistry and Metabolism of Plant Lipids (Wintermans, J. and Kuiper, P. eds), pp. 451-454. Amsterdam: Elsevier.

Pham Thi A, Borrel-Flood C, da Silva JV, Justin AM, Mazliak P. 1987. Effects of drought on [1-14C]?oleic and [1-14C]?linoleic acid desaturation in cotton leaves. Physiologia Plantarium 69:147-150.

Pham Thi A, da Silva JV , Mazliak P. 1990. The role of membrane lipids in drought resistance of plants. Bulletin de la Société Botanique de France, Actualités Botaniques 137:99-114.

Posas F, WurglerMurphy SM, Maeda T, Witten EA, Thai TC, Saito H. 1996. Yeast HOG1 MAP kinase cascade is regulated by a multistep phosphorelay mechanism in the SLN1-YPD1-SSK1 "two-component" osmosensor. Cell 86:865-875.

Quartacci MF, Navari-Izzo F. 1992. Water stress and free radical mediated changes in sunflower seedlings. Journal of Plant Physiology 139:621-625.

Ramanjulu S, Bartels D. 2002. Drought-and desiccation-induced modulation of gene expression in plants. Plant Cell \& Environment 25:141-151.

Rao S, Qayyum A, Razzaq A, Ahmad M, Mahmood I, Sher A. 2012. Role of foliar application of salicylic acid and 1-tryptophan in drought tolerance of maize. Journal of Animal and Plant Science 22:768-772.

Richardson AD, Berlyn GP. 2002. Changes in foliar spectral reflectance and chlorophyll fluorescence of four temperate species following branch cutting. Tree Physiology 22:499-506.

Robinson SP, Jones GP. 1986. Accumulation of Glycinebetaine in Chloroplasts Provides Osmotic Adjustment during Salt Stress. Australian Journal of Plant Physiology 13:659-668.

Sacks MM, Silk WK, Burman P. 1997. Effect of water stress on cortical cell division rates within the apical meristem of primary roots of maize. Plant physiology 114:519-527.

Sankar B, Jaleel CA, Manivannan P, Kishorekumar A, Somasundaram R, Panneerselvam R. 2007. Effect of paclobutrazol on water stress amelioration through antioxidants and free radical scavenging enzymes in Arachis hypogaea L. Colloids and surfaces B, Biointerfaces 60:229-235.

Sankar B, Jaleel CA, Manivannan P, Kishorekumar A, Somasundaram R, Panneerselvam R. 2008. Relative efficacy of water use in five varieties of Abelmoschus esculentus (L.) Moench. under water-limited conditions. Colloids and Surfaces B-Biointerfaces 62:125-129.

Santa-Cruz A, Perez-Alfocea F, Caro M, Acosta M. 1998. Polyamines as short-term salt tolerance traits in tomato. Plant Science 138:9-16.

Santner A, Estelle M. 2009. Recent advances and emerging trends in plant hormone signalling. Nature 459:1071-1078.

Schwab W. 2003. Metabolome diversity: too few genes, too many metabolites? Phytochemistry 62:837-849.

Schwabe W, Lionakis S. 1996. Leaf attitude in olive in relation to drought resistance. Journal of Horticultural Science 71.

Shao, H.B., Chu, L.Y., Shao, M.A., Jaleel, C.A. and Hong-mei, M., 2008. Higher plant antioxidants and redox signaling under environmental stresses. Comptes rendus biologies, 331:433-441.

Serrato AJ, Pérez-Ruiz JM, Spínola MC, Cejudo FJ. 2004. A novel NADPH thioredoxin reductase, localized in the chloroplast, which deficiency causes hypersensitivity to abiotic stress in Arabidopsis thaliana. Journal of Biological Chemistry 279:43821-43827.

Sharma P, Jha AB, Dubey RS, Pessarakli M. 2012. Reactive oxygen species, oxidative damage, and antioxidative defense mechanism in plants under stressful conditions. Journal of Botany 2012.

Sharp RE. 2002. Interaction with ethylene: changing views on the role of abscisic acid in root and shoot growth responses to water stress. Plant Cell and Environment 25:211-222.

Sharp RE, LeNoble ME. 2002. ABA, ethylene and the control of shoot and root growth under water stress. Journal of Experimental Botany 53:33-37.

Simms EL. 2000. Defining tolerance as a norm of reaction. Evolutionary Ecology 14:563-570.

Slama I, Abdelly C, Bouchereau A, Flowers T, Savouré A. 2015. Diversity, distribution and roles of osmoprotective compounds accumulated in halophytes under abiotic stress. Annals of Botany 115:433-447. 
Received:

December 28th, 2015

Accepted:

March 16th, 2016
Specht JE, Chase K, Macrander M, Graef GL, Chung J, Markwell JP, Germann M, Orf JH, Lark KG. 2001. Soybean response to water: A QTL analysis of drought tolerance. Crop Science 41:493-509.

Sun W, Van Montagu M, Verbruggen N. 2002. Small heat shock proteins and stress tolerance in plants. Biochimica et Biophysica Acta (BBA)-Gene Structure and Expression 1577: 1-9.

Sunkar R (Ed). 2010. Plant Stress Tolerance Methods and Protocols. New York: Humana Press.

Szabados L, Kovács H, Zilberstein A, Bouchereau A. 2011. Plants in extreme environments: Importance of protective compounds in stress tolerance. In: Turkan, I. ed. Advances in botanical research: Plant responses to drought and salinity stress-Developments in a post-genomic era. Amsterdam: Elsevier Ltd, 105-150.

Taiz L, Zeiger E. 2002. Plant Physiology. Sinauer Associates, Sunderland.

Takahashi T, Kakehi J-I. 2010. Polyamines: ubiquitous polycations with unique roles in growth and stress responses. Annals of Botany 105:1-6.

Tan D-X, Manchester LC, Helton P, Reiter RJ. 2007. Phytoremediative capacity of plants enriched with melatonin. Plant Signaling \& Behavior 2:514-516.

Turner N, Jones M. 1980. Turgor maintenance by osmotic adjustment: a review and evaluation. Adaptation of Plants to Water and High Temperature Stress, NC Turner, PJ Kramer eds, Adaptation of Plants to Water and High Temperature Stress. New York: Wiley Interscience, 87-103.

Turner NC. 1979. Drought resistance and adaptation to water deficits in crop plants. In: Mussell, H, Staples RC eds, Stress physiology in crop plants. New York: Wiley and Sons, 343-372.

Tuteja N, Sopory SK. 2008. Chemical signaling under abiotic stress environment in plants. Plant Signaling \& Behavior 3:525-536.

Tyree MT, Ewers FW. 1991. The hydraulic architecture of trees and other woody plants. New Phytologist 119:345-360.

Vakharia DN, Kukadia AD, Parameswaran M. 2003. Polyamines in response to artificial water stress in groundnut seedlings. Indian Journal of Plant Physiology 8:383-387.

van der Fits L, Memelink J. 2000. ORCA3, a jasmonate-responsive transcriptional regulator of plant primary and secondary metabolism. Science 289:295-297.

Vandoorne B, Mathieu A-S, Van den Ende W, Vergauwen R, Périlleux C, Javaux M , Lutts S. 2012. Water stress drastically reduces root growth and inulin yield in Cichorium intybus (var. sativum) independently of photosynthesis. Journal of Experimental Botany 63:4359-4373.

Verslues PE, Agarwal M, Katiyar-Agarwal S, Zhu J, Zhu JK. 2006. Methods and concepts in quantifying resistance to drought, salt and freezing, abiotic stresses that affect plant water status. Plant Journal 45:523- 539.

Verslues PE, Juenger TE. 2011. Drought, metabolites, and Arabidopsis natural variation: a promising combination for understanding adaptation to water-limited environments. Current Opinion in Plant Biology 14:240-245.

Wang W, Vinocur B, Shoseyov O, Altman A. 2004. Role of plant heat-shock proteins and molecular chaperones in the abiotic stress response. Trends in Plant Science 9:244-252.

Whitman CE, Travis RL. 1985. Phospholipid-composition of a plasma membrane-enriched fraction from developing soybean roots. Plant Physiology 79:494-498.

Wilson RF, Burke JJ, Quisenberry JE. 1987. Plant morphological and biochemical responses to field water deficits II. Responses of leaf glycerolipid composition in cotton. Plant Physiology 84:251-254.

Wullschleger SD, Yin TM, DiFazio SP, Tschaplinski TJ, Gunter LE, Davis MF, Tuskan GA. 2005. Phenotypic variation in growth and biomass distribution for two advanced-generation pedigrees of hybrid poplar. Canadian Journal of Forest Research 35:1779-1789.

Yancey PH, Clark ME, Hand SC, Bowlus RD, Somero GN. 1982. Living with water stress evolution of osmolyte systems. Science 217:1214-1222.

Yang S, Vanderbeld B, Wan J, Huang Y. 2010. Narrowing down the targets: towards successful genetic engineering of drought-tolerant crops. Molecular plant 3:469-490.

Zaefyzadeh M, Quliyev RA, Babayeva SM, Abbasov MA. 2009. The effect of the interaction between genotypes and drought stress on the superoxide dismutase and chlorophyll content in durum wheat landraces. Turkish Journal of biology 33:1-7.

Zhang JX, Nguyen HT, Blum A. 1999. Genetic analysis of osmotic adjustment in crop plants. Journal of Experimental Botany 50:291-302. 